\title{
Anaphylactoid reactions due to haemodialysis, haemofiltration, or membrane plasma separation
}

\author{
A J NICHOLLS, M M PLATTS
}

\begin{abstract}
A previously undescribed anaphylactoid reaction to haemodialysis, haemofiltration, or membrane plasma separation occurred in 15 patients receiving regular dialysis. The illness varied in severity from urticaria, sneezing, and watering of the eyes to severe bronchospasm and cardiovascular collapse, and began within a minute of blood being returned from the dialyser or filtration device to the patient. Reactions developed only when a dialyser sterilised with ethylene oxide was used for the first time and never after sterilisation with formalin. Several patients had more than one reaction while three had a reaction each time a new dialyser was used.

Incorrect priming of the dialysers may be a partial explanation of these attacks, but the exact reason for their occurrence is unknown. This is a dramatic and potentially life-threatening syndrome that may not previously have been recognised as a reaction to dialysis.
\end{abstract}

\section{Introduction}

Between September 1981 and March 1982, 15 patients receiving regular haemodialysis suffered 25 episodes of an acute anaphylactoid illness immediately after being connected to a disposable haemodialyser, haemofilter, or hollow fibre membrane plasma separator. Such reactions had never been seen in the previous 18 years of operation of the dialysis units in Sheffield, during which haemodialysis had been performed about a quarter of a

Department of Medicine, Royal Hallamshire Hospital, Sheffield S10 2JF

A J NICHOLLS, MB, MRCP, senior registrar in nephrology

$M$ M PLATTS, MD, FRCP, reader in medicine and consultant nephrologist million times. There had been no recent changes in dialysis technique or brands of dialyser used. Sixty per cent of our 150 regular haemodialysis patients used disposable dialysers while the remainder used Kiil-type dialysers. One brand of flat plate dialyser comprised about $80 \%$ of the disposable dialysers used.

The precise cause of the reactions was not ascertained, but we discovered an error in technique that may have been partially responsible. We therefore report these attacks to draw attention to a potentially lethal cornplication that may not at first be recognised as a reaction to a dialyser.

\section{Clinical syndrome}

All the reactions, 15 of which were witnessed by a doctor or dialysis nurse, began within a minute of the patient's blood beginning to flow through the dialyser or filter. They ranged in severity from sneezing, watering of the eyes, and urticaria to a frightening illness with bronchospasm, hypotension, flushing, headache, and chest pain. Observers of several of these attacks thought that the patient was about to die, although none did so (table). Recovery occurred within about 30 minutes if dialysis was stopped; milder reactions subsided spontaneously within two to three hours if dialysis was continued.

One patient (case 2) was disconnected from the dialyser when symptoms developed; half an hour later, when she felt better, she was reconnected. When her own blood, which had been stored in the dialyser, was reinfused she suffered an immediate recurrence of symptoms and dialysis had to be stopped. On the other hand, two patients (cases 6 and 7) who were reconnected after the blood had been discarded and the dialyser rinsed out with saline remained well.

Six patients suffered second or third attacks when they used a different batch or type of dialyser, but they subsequently used the original type of dialyser uneventfully.

Three patients (cases 8,10 , and 11) continued to have attacks every time they used a new flat plate disposable dialyser for the first time, even after the improved technique for setting up a dialyser described below was instituted. One of these patients was subsequently treated by continuous ambulatory peritoneal dialysis, but the two others were able to avoid major symptoms only by treating each new disposable dialyser with formalin before using it for the first time and by taking an oral antihistamine before dialysis. They had blood eosinophil counts of 0.62 and $0.91 \times 10^{9} / 1\left(620\right.$ and $\left.910 / \mathrm{mm}^{3}\right)$ respectively. Eosinophilia was not observed in the rest of our dialysis population. None of the patients had a history of asthma or atopy. 
Clinical features of anaphylactoid reactions

\begin{tabular}{|c|c|c|c|}
\hline $\begin{array}{l}\text { Case } \\
\text { No }\end{array}$ & $\begin{array}{l}\text { Device } \\
\text { used }\end{array}$ & Clinical features & Action taken and outcome \\
\hline 1 & HFD & Wheezing & $\begin{array}{l}\text { Dialysis stopped after } 30 \text { mins: } \\
\text { prompt recovery }\end{array}$ \\
\hline 2 & $\begin{array}{l}\text { HFD } \\
\text { FPD }\end{array}$ & $\begin{array}{l}\text { Severe wheezing } \\
\text { Severe wheezing; chest } \\
\text { pain; urticaria; } \\
\text { diarrhoea and } \\
\text { vomiting }\end{array}$ & $\begin{array}{l}\text { Ditto } \\
\text { Dialysis stopped after } 15 \text { mins: } \\
\text { blood recirculated; recovery after } \\
\text { one hour; reconnection to } \\
\text { dialyser; immediate recurrence of } \\
\text { symptoms }\end{array}$ \\
\hline \multirow[t]{3}{*}{3} & HFD & Sneezing, runny nose & $\begin{array}{l}\text { Dialysis completed; recovery within } \\
30 \text { mins after end of dialysis }\end{array}$ \\
\hline & FPD & Wheezing, urticaria & $\begin{array}{l}\text { Dialysis stopped after } 30 \mathrm{mins} \text { : } \\
\text { prompt recovery }\end{array}$ \\
\hline & FPD & $\begin{array}{l}\text { Sneezing, runny nose; } \\
\text { urticaria }\end{array}$ & $\begin{array}{l}\text { Dialysis stopped after } 60 \text { mins: } \\
\text { prompt recovery }\end{array}$ \\
\hline 4 & $\begin{array}{l}\text { HFD } \\
\text { FPD }\end{array}$ & $\begin{array}{l}\text { Chest pain } \\
\text { Urticaria; wheezing; } \\
\text { vomiting }\end{array}$ & $\begin{array}{l}\text { Ditto } \\
\text { Ditto }\end{array}$ \\
\hline 5 & $\begin{array}{l}\text { HFD } \\
\text { HFD }\end{array}$ & $\begin{array}{l}\text { Sneezing, runny nose } \\
\text { Sneezing, runny nose }\end{array}$ & $\begin{array}{l}\text { Ditto } \\
\text { Ditto }\end{array}$ \\
\hline 6 & $\mathrm{HF}$ & $\begin{array}{l}\text { Life-threatening } \\
\text { bronchospasm; } \\
\text { hypotension; } \\
\text { collapse }\end{array}$ & $\begin{array}{l}\text { Intravenous hydrocortisone and } \\
\text { aminophylline; blood rinsed from } \\
\text { haemofilter; flushed with saline; } \\
\text { reconnected; no problems }\end{array}$ \\
\hline 7 & MPS & $\begin{array}{l}\text { Acute bronchospasm; } \\
\text { hypotension; } \\
\text { flushing; chest pain }\end{array}$ & Ditto \\
\hline 8 & FPD & $\begin{array}{l}\text { Urticaria; severe } \\
\text { wheezing; } \\
\text { tachycardia; } \\
\text { headache } \\
\text { (Repeated stereotyped atta }\end{array}$ & $\begin{array}{l}\text { Dialysis stopped after one hour; } \\
\text { prompt recovery } \\
\text { cks with same dialyser (see text)) }\end{array}$ \\
\hline 9 & FPD & $\begin{array}{l}\text { Wheezing; severe chest } \\
\text { pain; hypotension }\end{array}$ & $\begin{array}{l}\text { Dialysis stopped after } 10 \text { mins: } \\
\text { admitted to hospital; spontaneous } \\
\text { recovery }\end{array}$ \\
\hline \multirow[t]{2}{*}{10} & HFD & Urticaria & \multirow{2}{*}{ 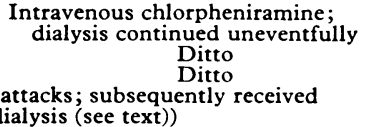 } \\
\hline & $\begin{array}{l}\text { FPD } \\
\text { FPD }\end{array}$ & $\begin{array}{l}\text { Urticaria } \\
\text { Urticaria } \\
\text { (Patient continued to have } \\
\text { continuous ambulatory }\end{array}$ & \\
\hline 11 & $\begin{array}{l}\text { FPD } \\
\text { FPD }\end{array}$ & $\begin{array}{l}\text { Severe wheezing; } \\
\text { urticaria; hypotension } \\
\text { Severe wheezing; } \\
\text { urticaria; } \\
\text { hypotension } \\
\text { (Repeated stereotyped atta }\end{array}$ & $\begin{array}{l}\text { Continued dialysis at home; slow } \\
\text { recovery after two hours'dialysis } \\
\text { Dialysis stopped after } 15 \text { mins: } \\
\text { prompt recovery. }\end{array}$ \\
\hline 12 & FPD & $\begin{array}{l}\text { Wheezing; sneezing; } \\
\text { chest pain; flushing; } \\
\text { runny eyes }\end{array}$ & $\begin{array}{l}\text { Dialysis completed; symptoms } \\
\text { improved spontaneously after one } \\
\text { hour of dialysis }\end{array}$ \\
\hline \multirow[t]{2}{*}{13} & FPD & $\begin{array}{l}\text { Severe wheezing; } \\
\text { chešt pain; urticaria }\end{array}$ & Ditto \\
\hline & FPD & $\begin{array}{l}\text { Severe wheezing; chest } \\
\text { pain; urticaria }\end{array}$ & $\begin{array}{l}\text { Dialysis stopped after } 15 \text { mins: } \\
\text { prompt recovery }\end{array}$ \\
\hline \multirow[t]{2}{*}{14} & FPD & $\begin{array}{l}\text { Severe wheezing; chest } \\
\text { pain; urticaria }\end{array}$ & $\begin{array}{l}\text { Dialysis completed; symptoms } \\
\text { improved spontaneously after two } \\
\text { hours of dialysis }\end{array}$ \\
\hline & FPD & $\begin{array}{l}\text { Severe wheezing; chest } \\
\text { pain; urticaria }\end{array}$ & $\begin{array}{l}\text { Dialysis stopped after } 15 \text { mins; } \\
\text { admitted to hospital; spontaneous } \\
\text { recovery }\end{array}$ \\
\hline 15 & FPD & $\begin{array}{l}\text { Severe wheezing; chest } \\
\text { pain; hypotension; } \\
\text { collapse; urticaria }\end{array}$ & Ditto \\
\hline
\end{tabular}

HFD $=$ Hollow fibre dialyser. $F P D=$ Flat plate dialyser. $\mathrm{HF}=$ Haemofilter. $\mathrm{MPS}=$ Membrane plasma separator.

\section{Dialysis methods}

The 15 patients had been treated by regular haemodialysis for from one to 10 years. Four different devices from four different manufacturers were used: a hollow fibre cuprophane haemodialyser (seven attacks), a disposable flat plate cuprophane haemodialyser (16 attacks), a hollow fibre anisotropic polysulfone haemofilter (one attack), and a hollow fibre cellulose acetate membrane plasma separator (one attack). The plasma separator was used to treat rejection in a renal transplant recipient previously treated by regular haemodialysis.

All the devices were flushed with one litre of physiological saline containing 5000 units of sodium heparin before use. The polyvinyl chloride blood lines, saline giving sets, heparin, and dialysate were of the same type as those used by all our patients receiving dialysis. New blood lines were used for each dialysis. Our patients reused disposable dialysers for from two to five times by rinsing them with saline and resterilising with $2 \%$ formalin. All the reactions occurred when a new dialyser was used for the first time; usually the dialyser was the first to be used from a new box of six. Reactions did not occur when dialysers had been sterilised in formalin. Thirteen reactions occurred in the home dialysis training unit, 10 in patients' homes, one in the transplant unit, and one in the acute dialysis ward. They were thus not related to the activities of a particular group of staff. Three of the reactions that occurred at home necessitated the patients' immediate admission to hospital.

\section{Possible causes of the reactions}

These reactions differed in several respects from previously described syndromes related to haemodialysis. Aljama et $a l^{1}$ described a patient with dialysis-triggered asthma and attributed it to an idiosyncratic response to cuprophane membranes. Two attacks in our patients, however, occurred during the use of devices not constructed of cuprophane. Furthermore, the symptoms in our patients started simultaneously with the return of blood to the circulation, with maximal severity at onset, whereas the patient reported on by Aljama et al developed slowly progressive bronchospasm over the first hour of dialysis.

These attacks also differed from asthma apparently related to acetate in the dialysate. ${ }^{2}$ Although acetate-containing dialysate was used for haemodialysis in our patients, the time course of the reactions was again very different from that in the previously reported case.

Two further well-recognised causes of adverse reactions to dialysis are pulmonary leukostasis with hypoxaemia ${ }^{3}$ and febrile rigors related to endotoxin. ${ }^{4}$ In the former syndrome there are no associated features of anaphylaxis, such as urticaria, sneezing, watering eyes, and hypotension, and the time course differs from that in our cases. Febrile episodes are related to improper sterilisation of dialysers with formalin so could not possibly have been implicated in our cases even if the symptoms had been similar.

The reactions described in this paper were clearly anaphylactoid because the systemic upset was typical of generalised histamine release. ${ }^{5}$ The two patients who continued to have regular reactions both had eosinophilia. Sensitisation that developed over a period rather than the direct effect of a toxin is suggested by the fact that reactions were not seen in patients who had received haemodialysis for less than one year. The reactions occurred in only 15 patients, although other patients were simultaneously using identical apparatus and methods.

The source of the antigen appeared to be a new haemodialyser or filter. Blood lines, saline, heparin, and dialysate were common to all types of dialyser whether new or reused and, therefore, could not be implicated.

The antigen was evidently readily removed from the dialyser since reactions did not occur when the same dialyser was reused. The obvious suspect was the ethylene oxide with which the devices were sterilised, although the non-pyrogenic endotoxin found by Petersen $e t a l^{6}$ in a large proportion of new disposable dialysers might have been responsible. The manufacturers of the flat plate haemodialyser assured us that they had not changed their sterilising methods recently and that the period of ventilation to remove ethylene oxide after sterilisation had not been curtailed. No excess of ethylene oxide was found by the manufacturers in remnants of batches of dialysers that had caused reactions. Other units using the same type of dialyser had apparently not noticed any adverse effects. A patient in Newcastle using a different brand of disposable dialyser suffered a cardiac arrest as a result of a reaction clinically similar to the ones described in this paper (Dr M K Ward, personal communication).

The manufacturers of the flat plate haemodialyser discussed the problem with us at length and came to our department to observe our technique. To our dismay and embarrassment we found that some of our patients and nurses were priming the dialysers incorrectly.

In a haemodialyser the blood and dialysis fluid flow countercurrently. When a new, dry sterilised dialyser is prepared for use the dialysate compartment is primed first. To eliminate air bubbles the flow should be from below upwards. The blood compartment is next filled with sterile, heparinised, physiological saline, and this should also be done from below upwards after the dialyser has been rotated through $180^{\circ}$. Finally, when haemodialysis is actually proceeding the dialyser is again inverted so that the patient's blood flows in at the top of the dialyser and the dialysis fluid, which is apt to carry air bubbles, flows in at the bottom.

Our incorrect priming of the blood compartment had been 
done from the top downwards. Although obvious air bubbles were eliminated, small bubbles in the interior of the dialyser could not be seen. Thus it seems probable that more gas (and hence conceivably residual ethylene oxide) remained within the dialyser with this technique.

We immediately rectified our technique, and no new patients developed the syndrome subsequently. None the less, three patients continued to have symptoms whenever they used a new disposable dialyser.

\section{Conclusion}

Although we have no absolute proof, we suggest that the following sequence of events may have occurred. Incorrect priming of the dialysers resulted in small amounts of ethylene oxide or some other easily removed substance remaining in small gas bubbles in the dialyser. This gradually sensitised some patients, who subsequently reacted to trace amounts in blood returning from incorrectly primed dialysers but were not affected by dialysers sterilised with formalin. Three patients became so sensitive that they continued to react to the even smaller amounts of ethylene oxide inevitably diffusing out of a dialyser despite proper preparation. An allergic reaction to ethylene oxide bound to albumin has been described previously.

This explanation is not, however, entirely satisfactory. We do not understand why these attacks appeared in an epidemic fashion in 1981, when there had been no obvious change in the technique of priming dialysers over the previous five years. The reactions were not attributable to faults in the manufacture or sterilisation of the dialysers since the products of four different firms were involved simultaneously.

We are grateful to Extracorporeal Ltd for the time, trouble, and expense expended by them in attempts to solve our problem. We continue to use their flat plate dialysers with confidence.

ADDENDUM-Since we submitted this paper a further patient who had not previously reacted to dialysis developed sneezing, wheezing, watery eyes, and urticaria within a minute of connection to a disposable flat plate dialyser. The dialyser had been properly primed in hospital. This further case strengthens our belief that incorrect priming of dialysers was not the sole cause of this syndrome.

\section{References}

1 Aljama P, Brown P, Turner P, Ward MK, Kerr DNS. Haemodialysistriggered asthma. $\mathrm{Br}$ Med $\mathcal{F} 1978$;ii :251-2.

${ }^{2}$ Hanai KEI, Horinchi T, Hanai J, et al. Hemodialysis-associated asthma in a renal failure patient. Nephron $1979 ; 25: 247-8$.

${ }^{3}$ Craddock PR, Fehr J, Dalmasso AP, Brigham KL, Jacob HS. Hemodialysis leukopenia. $\mathcal{F}$ Clin Invest 1979;59:879-88.

${ }^{4}$ Robinson PJA, Rosen SM. Pyrexial reactions during haemodialysis. Br Med f 1971 ;i:528-30.

${ }^{5}$ Neugebauer E, Lorenz W. Histamine in health and disease. Behringer Institute Mitteilungen $1981 ; 68: 102-33$.

6 Petersen NJ, Carson LA, Favero MS. Bacterial endotoxin in new and reused hemodialysers: a potential cause of endotoxemia. Trans Am Soc Artif Intern Organs $1981 ; 27: 155-9$.

${ }^{7}$ Poothullil J, Shimizu A, Day RP, Dolovich J. Anaphylaxis from the product(s) of ethylene oxide gas. Ann Intern Med 1975;82:58-60.

(Accepted 28 October 1982)

\title{
Haemophilia and the kidney: assessment after 11-year follow-up
}

\author{
M SMALL, P E ROSE, N McMILLAN, J J F BELCH, E B ROLFE, C D FORBES, J STUART
}

\begin{abstract}
Radiological and biochemical investigations of renal function were performed in 57 patients with haemophilia, 27 of whom had been previously investigated in 1969 . Although one-third of patients had a renal radiographic abnormality, only two had abnormalities persisting since 1969 and attributable to renal bleeding. Isotope renography was a sensitive indicator of renal abnormality whereas a history of haematuria was a poor discriminator for patients with abnormal intravenous urograms or impaired creatinine clearance. Haematuria was not associated with progressive loss of renal function and its natural history in haemophilia is probably benign.
\end{abstract}

\footnotetext{
University Department of Medicine and Department of Radiology, Royal Infirmary, Glasgow G4 OSF

M SMALL, MB, MRCP, registrar in medicine

N MCMILLAN, MB, DMRD, senior registrar in radiology

$\mathrm{J} J$ F BELCH, MB, MRCP, honorary registrar in medicine (presently lecturer in rheumatology, Centre for Rheumatic Diseases, Glasgow)

C D FORBES, MD, FRCP, senior lecturer in medicine
Departments of Haematology and Radiology, Queen Elizabeth Hospital, Birmingham B15 2TH
P E ROSE, MB, MRCP, senior registrar in haematology
E B ROLFE, BSC, FRCR, consultant radiologist

J STUART, MD, FRCPATH, professor of haematology
}

\section{Introduction}

Urinary tract bleeding is the most common manifestation of haemophilia after haemarthrosis. ${ }^{1}$ In addition, $20 \%$ of asymptomatic patients have subclinical microscopical haematuria. ${ }^{2}$ Several studies have also shown a high incidence of renal abnormalities in haemophilia, both by biochemical tests and by intravenous urography. ${ }^{2-5}$

In 1969 our two haemophilia centres (Glasgow and Birmingham) separately investigated ${ }^{2} 3$ two groups of patients with haemophilia with radiographic renal abnormalities (incidences of $38 \%$ and $36 \%$ respectively). It is clearly important to know whether these abnormalities were transient and of no long-term clinical importance or whether progressive renal damage has subsequently occurred. Renal function was therefore reassessed biochemically and radiologically in 27 patients from the two centres 11 years after the initial investigations. In addition, we have investigated a new series of 30 haemophiliacs adequately treated on demand or by self-therapy for at least five years to determine if the incidence of renal abnormalities has decreased as a consequence of more active treatment.

\section{Patients and methods}

Follow-up since 1969-Any change in renal function since 1969 was assessed in the 27 patients by the following investigations: (a) history of haematuria over the past five years graded as ++ -haematuria exceeding a collective total of three weeks or requiring two or more hospital admissions or both, + -haematuria of less than a total of three weeks or requiring one hospital admission or both, 0 -no clinical 